\title{
ЛАБОРАТОРНА ДІАГНОСТИКА ПОРУШЕНЬ ВУГЛЕВОДНОГО ОБМІНУ ДО ПОЯВИ КЛІНІЧНИХ ОЗНАК ТА НАЯВНІСТЬ КОМПОНЕНТІВ МЕТАБОЛІЧНОГО СИНДРОМУ В ДІТЕЙ НА РІЗНИХ СТАДІЯХ ОЖИРІННЯ
}

\author{
Лабораторна діагностика порушень вуглеводного \\ обміну до появи клінічних ознак та наявність \\ компонентів метаболічного синдрому в дітей на \\ різних стадіях ожиріння

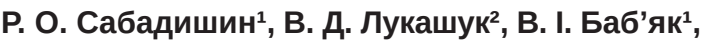 \\ О. П. Мялюк' ${ }^{1}$ О. В. Баб'як ${ }^{1}$ \\ кзВО «Рівненська медична академія» Рівненської \\ обласної ради \\ Національний медичний університет \\ імені О. О. Богомольця, Київ²
}

Резюме. Сукупність обмінних порушень, виявлених при ожирінні у дітей, є фрундаментом фрормування компонентів метаболічного синдрому (MC). Цей фракт лежить в основі розуміння критичної ролі дитячого ожиріння в розвитку виражених клінічних проявів МС у дорослих, хоча предикторні ознаки можуть бути виявлені й скориговані ще в дитячому віці.

Мета дослідження - визначити порушення вуглеводного обміну до появи клінічних ознак та наявність компонентів МС у дітей на різних стадіях ожиріння.

Матеріали і методи. Обстежено 37 дітей $з$ конституційно-екзогенним типом ожиріння і МС. Проведено лабораторне дослідження ліпідного обміну, трансаміназ, пероральний глюкозотолерантний тест (ПГГТ) та внутрішньовенний тест на толерантність до глюкози (ВГТТ).

Результати. Згідно з дослідженнями вже при ранніх стадіях у дітей відбувалися значні зміни в ліпідному обміні, що вели до розвитку МС. За результатами кількісних оцінок інсулінорезистентності у дітей із ожирінням I і /l ступенів реєструвались найбільш виражені зміни. Відзначено статистично достовірне зростання АЛТ і АСТ вже при I ступені ожиріння $(p<0,05)$, що зумовлює навантаження на серце та печінку при ранньому ожирінні, чим збільшує ризик виникнення патологій, що ведуть до розвитку МС. У групі осіб із помірним порушенням вуглеводного обміну спостерігалося зниження коефріцієнта швидкості продукції глюкози печінкою, порівняно з групою пацієнтів з ожирінням, але без порушень вуглеводного обміну. Більш вираженим і статистично значущим було зниження коефіцієнта швидкості елімінації глюкози в крові у групі з помірними порушеннями вуглеводного обміну, порівняно 3 пацієнтами з ожирінням, але без даних порушень $(p<0,05)$ і групою контролю $(p<0,05)$.

\author{
Laboratory diagnostics of disorders of carbohydrate \\ metabolism before the onset of clinical sings and \\ components of metabolic syndrome in children at \\ different stages of obesity \\ R. O. Sabadyshyn ${ }^{1}$, V. D. Lukashuk' ${ }^{2}$ V. I. Babiak ${ }^{1}$, \\ O. P. Mialiuk ${ }^{1}$, O. V. Babiak ${ }^{1}$ \\ Municipal Institution of Higher Education "Rivne Medical \\ Academy" Rivne Regional Council ${ }^{1}$ \\ O. Bohomolets National Medical University, Kyiv ${ }^{2}$
}

e-mail: oksankamp@ukr.net

Summary. The cumulative metabolic disorders are the foundation for the formation of metabolic syndrome components in obese children. That fact is at the centre of the understanding of the critical role of child obesity in the development of pronounced clinical manifestations of metabolic syndrome in adults, although early signs can be detected and corrected in children.

The aim of the study - to determine disorders of carbohydrate metabolism before the onset of clinical signs and components of metabolic syndrome in children at different stages of obesity.

Materials and Methods. We've examined 37 children with a constitutional-exogenous obesity and metabolic synt drome. Laboratory tests of lipid metabolism, transaminases, oral glucose tolerance test (OGTT) and intravenous glucose tolerance test (IVGTT) have been conducted.

Results. According to the study in children in the early stages of obesity, there have already been significant changes in lipid metabolism, leading to the development of metabolic syndrome. A qualitative assessment of insulin resistance in children with obesity of the first and second degrees, the most pronounced changes were recorded. Statistically significant was the increase in ALT and AST at the first degree of obesity $(p<0.05)$, which causes the strain on the heart and liver at early obesity, thus increasing the risk of pathologies leading to metabolic syndrome. In the group of persons with moderate impairment of carbohydrate metabolism, a decrease in the rate of hepatic glucose production was observed compared with the group of patients with obesity and normal carbohydrate metabolism. The decrease in the rate of elimination of glucose in the blood in the group with moderate impairment of carbohydrate mee tabolism was more pronounced and statistically significant compared with patients with obesity, but without these disorders $(p<0.05)$ and the control group $(p<0.05)$.

(C) P. О. Сабадишин та ін., 2020

ISSN 2706-6282(print)

ISSN 2706-6290(online)
Вісник медичних і біологічних досліджень

Bulletin of Medical and Biological Research 
Висновки. Виявлено високу частоту всіх компонентів МС. Маркерами початкових порушень вуглеводного обміну за даними ВГТТ були: високий рівень глікемії на 20 хв тесту (III і IV ступені ожиріння), зменшення швидкості зниження рівня глюкози і високий постпрандіальний рівень глікемії.

Ключові слова: метаболічний синдром; ожиріння; вуглеводний обмін; глюкозо-толерантний тест.

\section{ВСТУП}

Ожиріння - гетерогенна група спадкових і набутих захворювань, пов'язаних із надмірним накопиченням жирової тканини в організмі [1]. Багато проблем із здоров'ям, пов'язані з ожирінням, які, як раніше вважалося, відносяться тільки до дорослих, у даний час все частіше спостерігаються й у дітей: артеріальна гіпертензія, діабет 2 типу, неалкогольна жирова хвороба печінки, полікістозні зміни в яєчниках і утруднене дихання у сні, метаболічний синдром (МС). У 80 \% дітей 3 даною патологією реєструється підвищений артеріальний тиск. У 25 $\%$ дітей з ожирінням виявляється порушення толерантності до глюкози, ще у 4 \% - прихований цукровий діабет 2 типу [2].

Патогенез ожиріння складається з безлічі ланок, взаємопов'язаних між собою, що знаходяться під контролем нейроендокринної регуляції. Сукупність обмінних порушень, виявлених при ожирінні у дітей, лежить в основі фрормування компонентів МС, їх потенціює патологічна дія інсулінорезистентності (IP) і гіперінсулінемії (ГІ) протягом усього подальшого життя. Цей фракт лежить в основі розуміння критичної ролі дитячого ожиріння в розвитку виражених клінічних проявів МС у дорослих, хоча предикторні ознаки можуть бути виявлені й скориговані ще в дитячому віці [3]

Ожиріння у дітей супроводжується значним посиленням базальної продукції лептину, що розглядається як додатковий прогностичний маркер IP, MC і серцево-судинних захворювань [4]. Лептинорезистентність тканин і IP веде до патологічної активації процесів ліпосинтезу за рахунок реактивної ГІ. Підвищення рівня інсуліну в плазмі стимулює синтез вільних жирних кислот (ВЖК) в печінці. В жировій тканині інсулін підвищує проникнення всередину адипоцитів глюкози, велика частина якої використовується на синтез тригліцеридів (ТГ). 3 накопиченням ТГ у жирових клітинах з'являється тенденція до підвищення рівня ВЖК у крові, що забезпечує надходження в печінку великої кількості субстратів для синтезу ліпопротеїнів дуже низької щільності (ЛПДНщ). Високий рівень ліпідів і ліпопротеїнів залишаються стійкими протягом усього життя і $€$ предикторами атеросклерозу і IXC [5, 6].
Conclusions. Patients showed high frequency of all components of metabolic syndrome. We found a high level of glycemia at the 20 minute of the test (degrees 3 and 4 of obesity), a decrease in the rate of decline in glucose level and a high postprandial blood glucose concentration in case of initial carbohydrate metabolic disturbances according to the IVGTT.

Key words: metabolic syndrome; obesity; carbohydrate metabolism; glucose tolerance test

Метою дослідження було визначити порушення вуглеводного обміну до появи клінічних ознак та наявність метаболічного синдрому в дітей на різних стадіях ожиріння.

\section{МАТЕРІАЛИ I МЕТОДИ}

Дослідження проведено на базі КП «Рівненська обласна дитяча лікарня». Обстежено 37 осіб (19 дівчат, 18 юнаків), середній вік обстежуваних склав $(12,02 \pm 2,81)$ року. Всі пацієнти мали конституційно-екзогенний тип ожиріння і метаболічний синдром (MC, за класифрікацією IDF 2007 р.). Критеріями виключення були хворі з ожирінням ендокринного генезу і генетичною патологією, пацієнти з цукровим діабетом 1 і 2 типів, хворі, які отримують замісну гормональну терапію. Групу контролю склали 10 практично здорових дітей, відповідних за статтю та віком. Усім пацієнтам було проведено обстеження: аналізували стать, початок і тривалість захворювання, наявність хронічних вогнищ інфрекції, спадкову обтяженість з діабету, артеріальної гіпертензії, дисліпідемії, ожиріння, серцево-судинній патології, антропометрії, вимірюванні окружності талії (ОТ), стегон (ОС) 3 розрахунком їх співвідношення (ОТ/OC) і індексу маси тіла (IMT) за центильними таблицями T. Cole [7], SDS IMT. Лабораторні методи: рівень загального холестерину (ХС, норма до 5,0 ммоль/л), тригліцеридів (ТГ, норма 0,4-1,7 ммоль/л), ліпопротеїнів низької щільності (ЛПНЩ, норма до 2,6 ммоль/л ), ліпопротеїнів високої щільності (ЛПВщ, норма від 1,42 ммоль/л), індекс атерогенності (КА, норма до 2,0), трансаміназ (АСТ, АЛТ), лептин, антитіла до глутаматдекарбоксилази (Isletest TM-GAD, «BIOMERICA»), антитіла до $\beta$-клітин (Isletest TM-ICA, "BIOMERICA"), імунореактивний інсулін (IPI) імуноферментним методом (Mercodia Iso-Insulin ELISA, норма 5-25 ммоль/л). Ступінь інсулінорезистентності визначали за індексами HOMA i Caro.

Пероральний глюкозотолерантний тест (ПГГТ) проводили за стандартною методикою [8]. Внутрішньовенний тест на толерантність до глюкози (ВГТТ) виконували наступним чином: внутрішньовенно вводився $25 \%$ розчин глюкози з розрахунку 0,5 г/кг маси тіла, струминно, але не більше 35 г 3 наступним забором венозної крові на $0 ; 3 ; 5 ; 10$; 
20; 30; 45; 60; 90; 120 хв для визначення глюкози. Використовували метод аналізу результатів ВТТГ, що дозволяє визначити швидкість елімінації глюкози з крові (k-індекс) і індекс продукції глюкози печінкою (Н-індекс) за допомогою комп'ютерної програми, яка обчислює $\mathrm{H}$ - і k-параметри 3 авторського сайту за адресою www.diabet.ru/ Dreval/ivgtt_eng.exe.

Статистичну обробку отриманих результатів досліджень проводили з використанням загальноприйнятих методів варіаційної статистики за допомогою пакета статистичних програм Excel 2002 та Statistika for Windows (Statsoft Ins, США) [9]. Рівень вірогідності визначали за критерієм Стьюдента. Відмінності вважалися достовірними при рівні значимості $p<0,05$.

\section{РЕЗУЛЬТАТИ ТА ОБГОВОРЕННЯ}

У генеалогічному анамнезі у 80 \% обстежуваних спадковість обтяжена ожирінням, у 50 \% - цукровим діабетом 2 типу, в $24 \%$ - гіпертонічною хворобою. Стратифрікацію пацієнтів за ступенем ожиріння проводили згідно 3 класифікацією В. А. Петеркової, О. В. Васюкової (2013) за SDS IMT. При обстеженні I ступінь ожиріння виявлено у 6 осіб, II ступінь - в 13 осіб, III ступінь - в 8 осіб, IV ступінь - в 10 дітей. IMT склав $(35,8 \pm 5,7)$ кг. Середнє арифметичне початку набору маси - $(5,5 \pm 2,0)$ року, захворювання триває - $(7,4 \pm 4,3)$ року. За даними УЗД органів черевної порожнини жировий гепатоз діагностований у 14 осіб. За результатами лабораторного обстеження було виявлено збільшення рівня ХС, ТГ, ЛПНЩ, КА і зменшення рівня лПВЩ зі збільшенням ступеня ожиріння (табл. 1).

Згідно 3 нашими дослідженнями статистично достовірними виявилися зростання показників XС і ТГ у пацієнтів 3 II ступенем ожиріння $(p<0,05)$, а лПНЩ і КА в осіб із І ступенем ожиріння $(p<0,05)$. щодо лПВЩ, то вони активно знижувались вже при початковій стадії ожиріння $(p<0,05)$. Вищезазначене дає можливість припустити, що вже при ранніх стадіях (I і ІІ ступені ожиріння) у дітей відбуваються значні зміни в ліпідному обміні, що призводить до розвитку метаболічного синдрому й активного клінічного прояву його компонентів: сприяє розвитку серцево-судинної патології та цукрового діабету 2 типу.

За результатами кількісних оцінок інсулінорезистентності у дітей із ожирінням I і II ступенів реєстрували найвираженіші зміни $(p<0,05)$. Більш чутливим для оцінок виявився індекс Caro.

Вважається, що абдомінальний тип ожиріння говорить про інсулінорезистентність та гіперінсулінемію. За результатами проведеної роботи абдомінальне ожиріння (ОТ>0,9) спостерігали у 13 юнаків, в 9 (70 \%) з них підтверджено розрахунками, і у 12 дівчат, 3 яких у 7 (58 \%) також реєструвалися високі індекси інсулінорезистентності. Відзначено статистично достовірне зростання АЛТ і АСТ вже при І ступені ожиріння ( $p<0,05)$, що зумовлює навантаження на серце та печінку вже при початковій стадії ожиріння, чим збільшує ризик виникнення патологій, що ведуть до наростання ознак МС.

За результатами ПгТТ у 5 (14 \%) дітей виставлено діагноз - порушення глікемії натще й у такої ж кількості пацієнтів - порушення толерантності до глюкози. Згідно з даними ВГТТ виділяють пацієнтів із помірними порушеннями вуглеводного обміну і вираженими порушеннями вуглеводного обміну [10]. У дослідженні з ВГТТ, яке ми провели, у 10 осіб виявлено помірні порушення вуглеводного обміну. В групі цих пацієнтів спостерігали зниження коефіцієнта швидкості продукції глюкози печінкою $(\mathrm{H})$, порівняно 3 групою пацієнтів 3 ожирінням, але без порушень вуглеводного обміну. Більш вираженим і статистично значущим було зниження коефіцієнта швидкості елімінації глюкози в крові (k) в групі 3 помірними порушеннями вуглеводного обміну, порівняно $з$ пацієнтами 3 ожирінням, але без порушень вуглеводного обміну $(p<0,05)$ і групою контролю $(p<0,05)$ (табл. 2).

Таблиця 1. Лабораторні показники у дітей із різним ступенем ожиріння

\begin{tabular}{l|c|c|c|c|c}
\hline \multicolumn{1}{c|}{ Показник } & $\begin{array}{c}\text { Контрольна група } \\
(\mathrm{n}=10)\end{array}$ & I ступінь $(\mathrm{n}=6)$ & II ступінь $(\mathrm{n}=13)$ & III ступінь $(\mathrm{n}=8)$ & $\begin{array}{c}\text { IV ступінь } \\
(\mathrm{n}=10)\end{array}$ \\
\hline ХС & $2,7 \pm 1,0$ & $3,0 \pm 0,4$ & $4,5 \pm 0,4^{*}$ & $4,6 \pm 0,2$ & $5,0 \pm 0,4$ \\
\hline ТГ & $0,6 \pm 0,4$ & $0,7 \pm 0,2$ & $1,7 \pm 0,3^{*}$ & $1,9 \pm 0,6$ & $1,9 \pm 0,3$ \\
\hline ЛПВЩ & $2,3 \pm 0,2$ & $1,6 \pm 0,2^{*}$ & $1,5 \pm 0,4$ & $1,4 \pm 0,2$ & $1,2 \pm 0,3$ \\
\hline ЛПНЩ & $1,3 \pm 0,3$ & $2,3 \pm 0,3^{*}$ & $2,4 \pm 0,7$ & $2,6 \pm 0,6$ & $2,8 \pm 0,5$ \\
\hline КА & $0,8 \pm 0,2$ & $1,6 \pm 0,3^{*}$ & $1,7 \pm 0,6$ & $1,8 \pm 0,6$ & $2,0 \pm 0,6$ \\
\hline АЛТ & $17,8 \pm 3,1$ & $27,8 \pm 3,2^{*}$ & $28,9 \pm 4,1$ & $29,6 \pm 3,0$ & $38,9 \pm 3,2^{*}$ \\
\hline AСТ & $19,0 \pm 3,9$ & $29,8 \pm 3,1^{*}$ & $30,8 \pm 5,2$ & $31,2 \pm 3,8$ & $41,9 \pm 3,3^{*}$ \\
\hline Hома & $2,6 \pm 0,5$ & $4,6 \pm 0,7^{*}$ & $6,7 \pm 0,7^{*}$ & $6,5 \pm 0,6$ & $6,6 \pm 1,7$ \\
\hline Caro & $0,43 \pm 0,06$ & $0,39 \pm 0,02$ & $0,34 \pm 0,02^{*}$ & $0,32 \pm 0,05$ & $0,29 \pm 0,05$ \\
\hline
\end{tabular}

Примітка. * - p<0,05 - достовірність відмінностей між групами.

ISSN 2706-6282(print)

ISSN 2706-6290(online)
Вісник медичних і біологічних досліджень Bulletin of Medical and Biological Research
1,2020 
Таблиця 2. Показники внутрішньовенного тесту на толерантність у дітей з ожирінням

\begin{tabular}{l|c|c|c}
\hline Коесріцієнт & Контрольна група $(\mathrm{n}=10)$ & $\begin{array}{c}\text { Діти з порушенням вуглевод- } \\
\text { ного обміну }(\mathrm{n}=10)\end{array}$ & $\begin{array}{c}\text { Діти без порушення вуглевод- } \\
\text { ного обміну }(\mathrm{n}=27)\end{array}$ \\
\hline $\mathrm{H}$ & $2,65 \pm 0,9$ & $3,48 \pm 1,5$ & $3,57 \pm 1,6$ \\
\hline $\mathrm{k}$ & $2,38 \pm 0,5$ & $1,09 \pm 0,3^{*}$ & $2,77 \pm 0,7^{\star *}$ \\
\hline
\end{tabular}

Примітки: 1) * - р<0,05 - достовірність відмінностей між групою контролю та групою дітей із помірними порушеннями вуглеводного обміну; 2 ** - p<0,05 - достовірність відмінностей між групою дітей з помірними порушеннями вуглеводного обміну та групою дітей без порушень вуглеводного обміну.

Продукція глюкози печінкою у хворих на жировий гепатоз $(3,22 \pm 0,9)$ практично не відрізнялася від швидкості утворення глюкози у пацієнтів без даного ускладнення $(3,38 \pm 1,1)$, але була вищою, ніж у контрольній групі $(2,65 \pm 0,9)$. У здорових дітей через 2 год тесту спостерігалося зниження рівня глюкози до показників норми. У пацієнтів з ожирінням усіх ступенів відзначався більш високий під- йом рівня глюкози і більш високі показники глікемії на 120 хв. При порівнянні кінетики глюкози під час ВГТТ у пацієнтів III і IV ступенів ожиріння відзначався менший підйом рівня глюкози на 5 і 10 хв, значне зростання показників глюкози на 20 хв дослідження і зменшення швидкості зниження її рівня, а також найвищий постпрандіальний рівень глюкози (рис.).

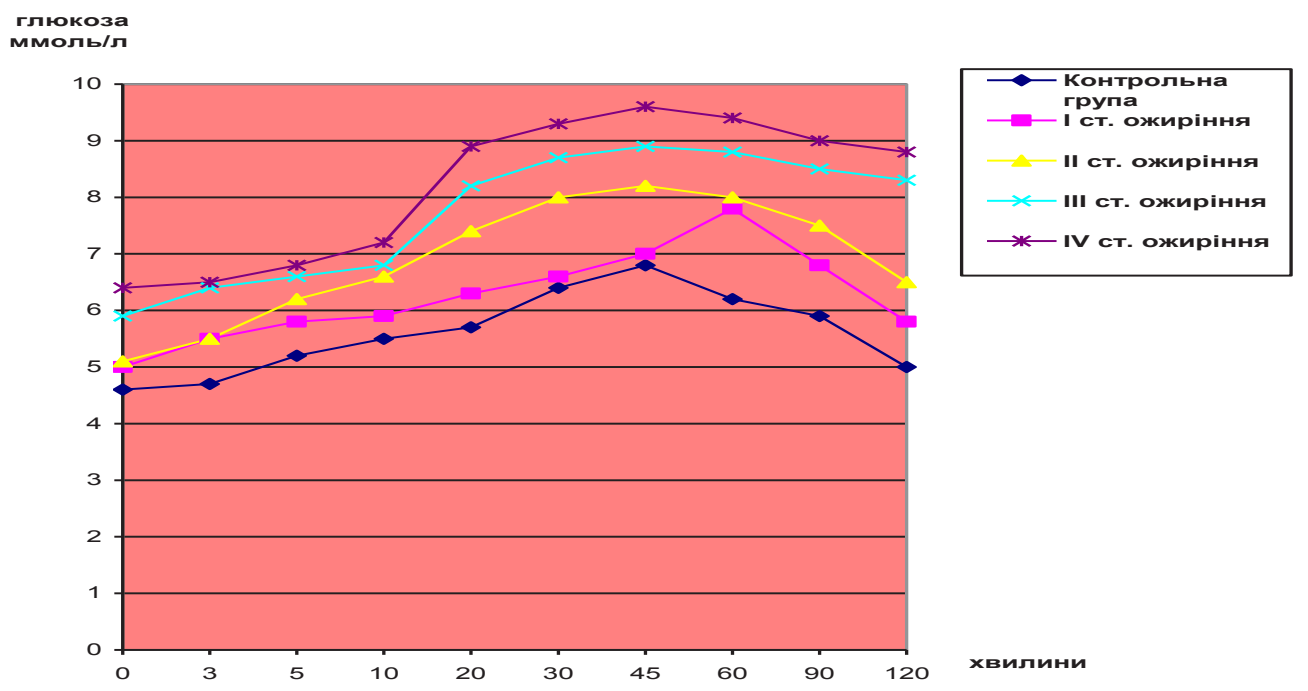

Рис. Динаміка середніх значень глюкози у дітей із різним ступенем ожиріння при проведенні внутрішньовенного тесту на толерантність.

\section{Висновки}

Обтяжена спадковість 3 ожиріння, цукрового діабету 2 типу та гіпертонічної хвороб $є$ значимим фрактором у формуванні метаболічних порушень у дітей 3 I і II ступенями ожиріння. Згідно 3 нашим дослідженням було виявлено високу частоту всіх компонентів метаболічного синдрому: абдоміналь-

\section{СПИСОК ЛІТЕРАТУРИ}

1. Российская ассоциация эндокринологов : рекомендации по диагностике, лечению и профрилактике ожирения у детей и подростков. - М., 2015.

2. Association of all-cause mortality with overweight and obesity using standard body mass index categories: a systematic review and meta-analysis / K. M. Flegal, B. K. Kit, H. Orpana [et al.] // JAMA. - 2013. - No. 309 (1). P. 71-82.

3. Obesity and overweight. Report of a WHO Consultał tion on Obesity. WHO Technical report Series, 2016. не ожиріння (68\%), інсулінорезистентність (51 \%), дисліпідемію (47 \%) і артеріальну гіпертензію (38 \%). Маркерами початкових порушень вуглеводного обміну за даними ВГТТ були: високий рівень глікемії на 20 хв тесту (III і IV ступені ожиріння), зменшення швидкості зниження рівня глюкози і високий постпрандіальний рівень глікемії.

4. Дитяча ендокринологія в Україні у 2018 році / [Н. Б. Зелінська, Н. Г. Руденко, Є. В. Глоба та ін.] // Український журнал дитячої ендокринології. - 2019. - № 1. - C. 7-15. - Режим доступу: http://nbuv.gov.ua/UJRN/ ujde_2019_1_4 (дата звернення 15.02.2020) - Назва 3 екрана.

5. Факторы риска сердечно-сосудистых заболеваний у лиц с высоким нормальным артериальным давлением в Российской Федерации (по данным эпидемиологического исследования ЭССЕ-РФ) / 
Ю. Є. Ефремова, Е. В. Ощепкова, Ю. В. Жернакова [и др.] // Системные гипертензии. - 2017. - № 14 (1). C. 6-11.

6.International society for pediatric and adolescent diabetes (ISPAD) Clinical Practice Consensus Guidelines. $-2014$.

7. Establishing a standard definition for child overweight and obesity worldwide: international survey / T. J. Cole, M. C. Bellizzi, K. M. Flegal [et al.] // BMJ. - 2000. Vol. 320. - P. 1-6.

\section{REFERENCES}

1. Russian Association of Endocrinologists. Recommendations for the diagnosis, treatment and prevention of obesity in children and adolescents [Российская ассоциация эндокринологов. Рекомендации по диагностике, лечению и просрилактике ожирения у детей и подростков] Moscow. 2015. Russian.

2. Flegal KM, Kit BK, Orpana H, Graubard BI. Association of all-cause mortality with overweight and obesity using standard body mass index categories: a systematic review and meta-analysis. JAMA. 2013;309(1): 71-82.

3. Obesity and overweight. Report of a WHO Consultat tion on Obesity. WHO Technical report Series. 2016.

4. Zelinska NB, Rudenko NH, Hloba YeV, Shevchenko IYu, Kavetska YuS. [Pediatric endocrinology in Ukraine in 2018]. Ukr zhurnal dytiachoi endokrynolohii. 2019;1: 7-15. Availh able from: http://nbuv.gov.ua/UJRN/ujde_2019_1_4 [Accesse February 2020]. Ukrainian.

5. Efremova YuE, Oshchepkova EV, Zhernakova YuV, Chazova IE, Jarovaja EB, Shalnova SA, etal. [Cardiovascular risk factors in people with high normal blood pressure in
8. Дедов И. И. Алгоритмы специализированной медицинской помощи больным сахарным диабетом / И. И. Дедов, М. В. Шестакова. - М., 2013. - 120 с.

9. Rebrov O. Statystical analysis of medical results. Application of package program STATISTICA/Rebrov O. - M. : Medyasfera, 2002. - $312 \mathrm{p}$.

10. Дедов И. И. Программа помощи детям с эндокринными заболеваниями «Альфра-Эндо» I И. И. Дедов, В. А. Петеркова, А. В. Карпушкина // Проблемы эндокринологии. - 2015. - № 2. - С. 50-54.

Russian population (based on data obtained in ESSE-RF epidemiological study)]. Sistemnye gipertenzii. 2017;14(1): 6-11. Russian.

6. International society for pediatric and adolescent diabetes (ISPAD) Clinical Practice Consensus Guidelines. 2014.

7. Cole TJ, Bellizzi MC, Flegal KM, Dietz WH. Establishing a standard definition for child overweight and obesity worldwide: international survey. BMJ. 2000;320: 1-6.

8. Dedov II, Shestakova MV. Algorithms for specialized medical care for patients with diabetes. [Алгоритмы специализированной медицинской помощи больным сахарным диабетом] Moscow; 2013. Russian.

9. Rebrov O. Statystical analysis of medical results. Application of package program STATISTICA. [Статистический анализ медицинских данных. Применение пакета прикладных программ STATISTICA] M: Mediasfera; 2002. Russian.

10. Dedov II, Peterkova VA, Karpushkina AV. ["Alfa-Endo" program for helping children with endocrine diseases]. Problemy endokrinologii. 2015;2: 50-4. Russian. 